\title{
Quercetin - A Flavonoid Compound from Sarcopyramis bodinieri var delicate with Potential Apoptotic Activity in HepG2 Liver Cancer Cells
}

\author{
Weifeng Huang ${ }^{2}$, Chunpeng Wan $^{1 *}$ and Shouran Zhou ${ }^{3}$ \\ ${ }^{1}$ Jiangxi Key Laboratory for Postharvest Technology and Nondestructive Testing of Fruits \& Vegetables, College of Agronomy, \\ Jiangxi Agricultural University, Nanchang 330045, ${ }^{2}$ Medical College, China Three Gorges University, Yichang 443002, ${ }^{3}$ Jiangxi \\ University of Traditional Chinese Medicine, Nanchang 330006, China
}

*For correspondence: Email: lemonwan@126.com; Tel: +86 791 83813185; Fax: +86 791 83813185;

Revised accepted: 25 July 2013

\begin{abstract}
Purpose: To isolate and identify the cytotoxicity of the constituents of Sarcopyramis bodinieri var. delicate.

Methods: S. bodinieri var. delicate was extracted with hydrochloric acid-methanol and fractionated with ethyl acetate further. The chemical constituents of the ethyl acetate fraction were purified by a combination of D101 macroporous resin and Sephadex LH-20 column chromatography. The structure was characterized by ${ }^{1} \mathrm{H}$-Nuclear Magnetic Resonance (NMR) and electrospray ionization tandem mass spectrometry (ESI-MS). Apoptosis was evaluated by fluorescence staining and Western blot analysis using 4,6-diamidino-2-phenylindole (DAPI) staining and poly (ADP-ribose) polymerase (PARP) SDSPAGE tests in HepG2 liver cancer cells.

Results: One flavonoid with high purity was purified by the combination of D101 macroporous resin and Sephadex $\mathrm{LH}-20$ column chromatography. The flavonoid compound was identified as quercetin by ${ }^{1} \mathrm{H}-$ NMR and ESI-MS analyses. DAPI staining and PARP SDS-PAGE tests showed $60 \mu M$ quercetin could induce potential apoptotic activity in HepG2 liver cancer cells.

Conclusion: Quercetin was the major cytotoxicity constituent in S. bodinieri var. delicate.
\end{abstract}

Keywords: Apoptotic activity, Quercetin, Sarcopyramis bodinieri var. delicate, HepG2 liver cancer cells, Electrospray ionization tandem

Tropical Journal of Pharmaceutical Research is indexed by Science Citation Index (SciSearch), Scopus, International Pharmaceutical Abstract, Chemical Abstracts, Embase, Index Copernicus, EBSCO, African Index Medicus, JournalSeek, Journal Citation Reports/Science Edition, Directory of Open Access Journals (DOAJ), African Journal Online, Bioline International, Open-J-Gate and Pharmacy Abstracts

\section{INTRODUCTION}

Sarcopyramis genus belongs to the family of Melastomataceae, containing of 4 species and 2 varietas in china [1]. Many of the species are medicinal plants used in clinics and/or as folk medicines to treat liver and other inflammatory diseases. S. bodinieri var. delicate is a traditional Chinese medicinal (TCM) plant, widely used as a hepatoprotective drug in China.

A previous study has showed that the water extract of this herb could reduce aminotrans- ferase and cure choleplania and hepatoma in vivo [2]. However, the active constituents have not been isolated and identified. The ethyl acetate extract of of $S$. bodinieri var. delicate was reported to demonstrate promising antioxidant and free radical scavenging activities in vitro [3]. Our group is interested in isolating and identifying bioactive compounds from folk medicinal and edible plant species. As part of this research program, we recently carried out a completely investigation of the chemical constituents of $S$. bodinieri var. delicate [4-6]. Two new and many known flavonoid and 
phenolic compounds were isolated, and their major structures identified as the glycosides and/or acylated glycosides of quercetin, isorhamnetin and kaempferol [4-6].

This paper herein describes a quick method to isolate quercetin, a major active flavonoid compound, from the methanol- $\mathrm{HCl}$ extract of $S$. bodinieri var. delicate and the evaluation of the apoptotic activity of quercetin in vitro using 4,6diamidino-2-phenylindole (DAPI) staining and poly (ADP-ribose) polymerase (PARP) SDSPAGE tests in HepG2 liver cancer cells.

\section{EXPERIMENTAL}

\section{Plant material}

The specimen of $S$. bodinieri var. delicate was collected from Fujian Province, P.R. China, in April 2007 and authenticated by Xiuhong Zhou (a senior gardener of Yongchun Forestry Bureau). A voucher specimen (RSC07) was deposited at the herbarium of the Medical College, Xiamen University. The plant material dried at $40{ }^{\circ} \mathrm{C}$ in an air oven for $48 \mathrm{~h}$ and finely powdered.

\section{Equipment and chemicals}

The ${ }^{1} \mathrm{H}-\mathrm{NMR}$ spectra were recorded on a Bruker Avance-600 FT-NMR spectrometer, with tetramethylsilane (TMS) internal standard. ESIMS spectra were recorded on 3200 Q-trap ESIMS spectrometer (ABI, USA). Column chromatography was carried out with D101 macroporous resin (Cangzhou Bonchem Co. Ltd., China) and Sephadex LH-20 (Pharmacia Co., USA). HPLC-grade methanol was purchased from Merck Company (Darmstadt, Germany). All other organic solvents used were of analytical grade and purchased from Sinopharm Chemical Reagent Co, Ltd (Shanghai, China). A Shimadzu LC-20AT HPLC system was used to analyze and quantify the content of quercetin. 4,6-diamidino-2phenylindole (DAPI), Anti-poly (ADP-ribose) polymerase (PARP) and dimethyl sulfoxide (DMSO) were obtained from Sigma Chemical Company. The cell culture medium (DMEM; high glucose, without sodium pyruvate) and fetus bovine serum (FBS) were purchased from Hyclone Company. Acrylamide/bis solution (30 $\%$, 29:1) was bought from Bio-Radlaboratories, Inc. Protein content was tested using a BCA kit (Thermo Scientific).

\section{Cell line and culture}

The human hepatic cancer cells line, HepG2, was purchased from American Type Culture
Collection. HepG2 Cells were cultured in DMEM medium supplemented with $10 \%$ heat inactivated fetal bovine serum (FBS), $2 \mathrm{mM} \mathrm{L-}$ glutamine, 100 units $/ \mathrm{ml}$ penicillin and $100 \mu \mathrm{g} / \mathrm{ml}$ streptomycin at $37{ }^{\circ} \mathrm{C}$ in a humidified incubator

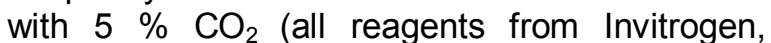
Carlsbad, CA). The cells were maintained in log phase by seeding twice a week at a density of 1 $\times 10^{5} / \mathrm{ml}$, and the experiments were performed 1 day after trypsinization.

\section{HPLC analysis}

The dried plant material $(1 \mathrm{~g})$ was extracted with $20 \mathrm{ml} 60 \%$ methanol \{with or without $10 \% \mathrm{HCl}$ $(4: 1, v / v)\}$ in a conical flask and refluxed at $80{ }^{\circ} \mathrm{C}$ for $2 \mathrm{~h}$. The acid extract was neutralized with $\mathrm{Na}_{2} \mathrm{CO}_{3}$. Both extracts were all conducted on HPLC analysis.

The HPLC system consisted of a Shimadzu LC20A pump, a CTO-20A column oven and SPDM20A dual absorbance detector (DAD). LCsolution software was used for controlling the analytical system and data processing. The analytical column is a shimpack VP-ODS column $(150 \mathrm{~mm} \times 4.6 \mathrm{~mm}, 5 \mu \mathrm{m})$ with a flow rate at 1.0 $\mathrm{mL} / \mathrm{min}$ and injection volume of $20 \mu \mathrm{L}$. A gradient solvent system consisting of solvent $A(0.1 \%$ aqueous trifluoroacetic acid) and solvent $B$ $(\mathrm{MeOH})$ was used as follows: 0 - $15 \mathrm{~min}$, from 10 to $30 \% \mathrm{~B} ; 15-25 \mathrm{~min}$, from 30 to $40 \% \mathrm{~B} ; 25-40$ min, from 40 to $50 \% \mathrm{~B} ; 40$ - $50 \mathrm{~min}$, from 50 to $70 \% \mathrm{~B}$. The chromatograms for the S. bodinieri var. delicate extracts are shown in Figure $1 \mathrm{~A}$ and $B$, respectively. The chromatograms were monitored at a broad spectrum window of 210 $600 \mathrm{~nm}$ and are shown at $365 \mathrm{~nm}$ in Figure 1.

\section{Extraction and isolation of quercetin}

The dry plant powder $(100 \mathrm{~g})$ were extracted with $1000 \mathrm{ml}$ a mixture of $60 \%$ methanol and $10 \%$ $\mathrm{HCl}(4: 1, v / v)$ in a conical flask and refluxed at 80 ${ }^{\circ} \mathrm{C}$ for $2 \mathrm{~h}$. The extract was neutralized with $\mathrm{Na}_{2} \mathrm{CO}_{3}$ and then concentrated under vacuum to dryness. The concentrate was dissolved and suspended in $300 \mathrm{ml}$ water and liquid-liquid extracted with ethyl acetate $(300 \mathrm{ml}$, three times). The ethyl acetate extracts were purified by D101 macroporous resin column chromatography, eluted with a serials of different concentration of ethanol $(0 \%, 30 \%$ and $70 \%$, respectively). Fraction 3 (70\% ethanol eluted fraction) was subjected to a Sephadex LH-20 column $(4.0 \mathrm{~cm}$ $\times 140 \mathrm{~cm}$ ) eluted with methanol to yield compound 1 (41.3 mg).

Trop J Pharm Res, August 2013;12 (4): 530 


\section{Quantification of the total content of quercetin by HPLC}

The determination of the total content of quercetin in $S$. bodinieri var. delicate was reported previously [7]. The mobile phase were consists of methanol and water $(0.1 \%$ phosphoric acid buffer) (45:55), the flow rate was at $1.0 \mathrm{ml} / \mathrm{min}$, separations temperature was at 40 ${ }^{\circ} \mathrm{C}$ and the detection wavelength was set at 365 $\mathrm{nm}$. The injection volume was $20 \mu \mathrm{l}$.

\section{Evaluation of cell apoptosis by DAPI staining}

The nuclear morphological changes associated with apoptosis were analyzed using DAPI staining [8]. $10 \mathrm{ml}$ HepG2 Cells suspension $(1 \times$ $105 / \mathrm{ml}$ ) were cultured in a $10 \mathrm{~mm}$ petri dish with 2-3 cover slips, allowed to attach overnight, then the cell exposed to vehicle (for control) or $60 \mu \mathrm{M}$ quercetin (for experimental group) respectively. After $48 \mathrm{~h}$, the cells were washed with PBS and fixed with $95 \%$ ethanol for $15 \mathrm{~min}$ at room temperature. The fixed cells were washed with PBS again and stained with $100 \mathrm{ng} / \mathrm{ml}$ DAPI solutions for $10 \mathrm{~min}$ at room temperature, then washed twice with PBS. Cells with condensed and fragmented DNA (apoptotic cells) were scored under a fluorescence microscope (Carl Zeiss, Germany) at × 40 objective lens magnification.

\section{Evaluation of cell apoptosis by Western Blotting}

Cells treated and untreated (for control) with 60 $\mu \mathrm{M}$ quercetin were lysed by adding Lysis Buffer RIPA (150 mM NaCl; 50 mM Tris $\mathrm{pH}$ 8; $0.1 \%$ SDS; $0.5 \%$ sodium deoxicolate; $1 \%$ Nonidet $\mathrm{P} 40$ ), centrifuged to separate non-soluble material. The protein content in the lysates was measured by BCA protein assay. Then $40 \mu \mathrm{g}$ soluble proteins were subjected to SDSpolyacrylamide gel electrophoresis (SDS-PAGE). The detection was achieved using the Immobilon Western Chemiluminescent HRP Substrate kit (Millipore). Primary antibodies are: PARP (Santa Cruz Biotechnology, Inc., sc-7150, 1:1000) and GAPDH (Sigma-Aldrich, G8795, 1:5000).

\section{Statistical analysis}

All experiments were performed in triplicate. Statistical analysis of the data was carried out by Microsoft Excel XP and differences were considered significant at $p<0.05$.

\section{RESULTS}

\section{Structure elucidation of compound 1}

Compound 1 was obtained as yellow powder, UV-vis $(\mathrm{MeOH}) \lambda_{\max }=370,256 \mathrm{~nm}$; ESI-MS m/z: 301 [M-H]. ${ }^{1} \mathrm{H}-\mathrm{NMR}$ (DMSO-d, $\left.600 \mathrm{MHz}\right)$ $\delta: 12.50(1 \mathrm{H}, \mathrm{s}, 5-\mathrm{OH}), 7.68(1 \mathrm{H}, \mathrm{d}, J=2.2 \mathrm{~Hz}, \mathrm{H}-$ $\left.2^{\prime}\right), 7.54\left(1 \mathrm{H}, \mathrm{dd}, J=2.2,8.4 \mathrm{~Hz}, \mathrm{H}-6^{\prime}\right), 6.88(1 \mathrm{H}$, $\left.\mathrm{d}, J=8.4 \mathrm{~Hz}, \mathrm{H}-5^{\prime}\right), 6.40(1 \mathrm{H}, \mathrm{d}, J=2.0 \mathrm{~Hz}, \mathrm{H}-8)$, $6.19(1 \mathrm{H}, \mathrm{d}, \mathrm{J}=2.0 \mathrm{~Hz}, \mathrm{H}-6)$. ${ }^{1} \mathrm{H}-\mathrm{NMR}$ spectrum showed two peaks at $\delta 6.19(1 \mathrm{H}, \mathrm{d}, J=2.0 \mathrm{~Hz})$ and $6.40 \mathrm{ppm}(1 \mathrm{H}, \mathrm{d}, J=2.0 \mathrm{~Hz})$ consistent with the meta protons $\mathrm{H}-6$ and $\mathrm{H}-8$ on A-ring and an ABX system at $7.68\left(1 \mathrm{H}, \mathrm{d}, \mathrm{J}=2.2 \mathrm{~Hz}, \mathrm{H}-2^{\prime}\right), 7.54$ $\left(1 \mathrm{H}, \mathrm{dd}, J=2.2 \mathrm{~Hz}, 8.4 \mathrm{~Hz}, \mathrm{H}-6^{\prime}\right)$ and $6.88(1 \mathrm{H}$, d, $J=8.4 \mathrm{~Hz}, \mathrm{H}-5^{\prime}$ ) corresponding to the catechol protons on B-ring. ${ }^{1} \mathrm{H}-\mathrm{NMR}$ data were consistent with those reported in the literature for the compound [4]. Compound 1 was identified as quercetin (1).

\section{HPLC results for methanol extracts with or without $\mathrm{HCl}$}

As depicted in Figure 1, the HPLC chromatography of the methanol extract showed at least 6 peaks while only 3 dominant peaks were detected in the methanol- $\mathrm{HCl}$ extract. The peak 1 was identified as quercetin. The content of quercetin was higher in methanol-HCl extract than in methanol extract, which showed that many quercetin glycosides were presented in the plant.

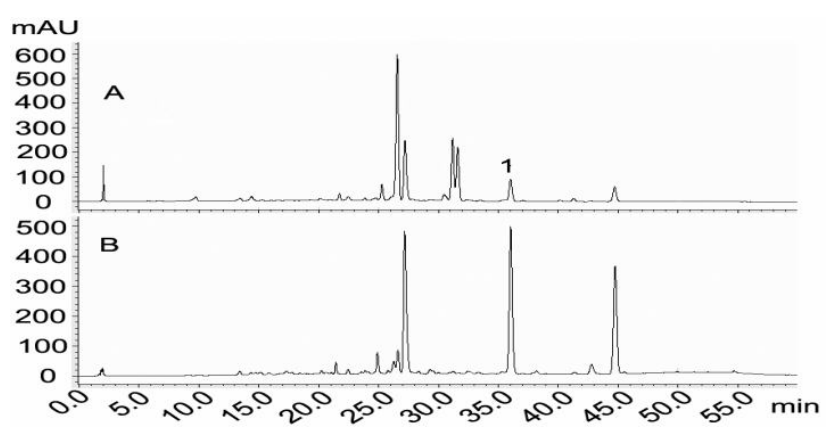

Figure 1: HPLC-DAD chromatogram of $S$. bodinieri var. delicate extracts. Peak 1 is quercetin; (A) Extracted with $60 \%$ methanol; (B) Extracted with methanol- $\mathrm{HCl}(4: 1, \mathrm{v} / \mathrm{v})$.

\section{Total content of quercetin}

The standard curve of quercetin was $Y=7.74 \times$ $10^{7} X-2.69 \times 10^{5}(X$ is the concentration of quercetin and $Y$ is the peak area integral value of quercetin). Quercetin's linearity range was 0.025 - $0.4 \mathrm{mg} / \mathrm{ml}$, with a mean correlation coefficient $r$ $=0.9998$. The content of quercetin in $S$. bodinieri var. delicate was $1.37 \mathrm{mg} / \mathrm{g}$. 
Quercetin induction of apoptosis of HpeG 2 cells

Quercetin is a promising cancer chemopreventive agent, we exploiting DAPI staining to observe nuclear morphological changes. As observed in Figure 2, we noticed that the untreated HepG2 cells displayed a normal, healthy nuclear shape, whereas the cells treated with $60 \mu \mathrm{M}$ quercetin for $24 \mathrm{~h}$ demonstrated bright, condensed chromatin and a fragmented nucleolus, which are regarded as hallmarks of apoptosis.

Control

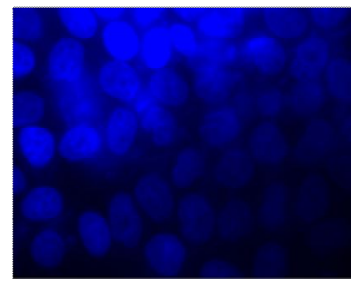

Quercetin

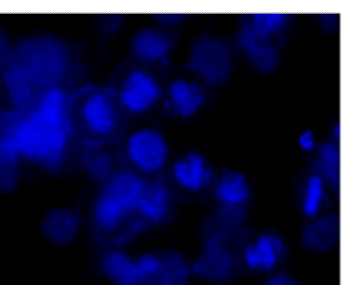

Figure 2: Apoptosis induced by quercetin in HepG2 cells. HepG2 cells treated with quercetin $(60 \mu \mathrm{M} / 24 \mathrm{~h})$ were immunostained with DAPI.

To further confirm the induction of apoptosis by quercetin, Western blot was conducted to detect the PARP cleavage. HepG2 cells treated with 60 $\mu \mathrm{M}$ quercetin at different time points and the cells collected for Western blot assay. Western blot result indicate that quercetin induced the cleavage of PARP in HepG2 cells after $24 \mathrm{~h}$ (Figure 3). The results suggest that quercetin efficiently induced the apoptosis of HepG2 cells.

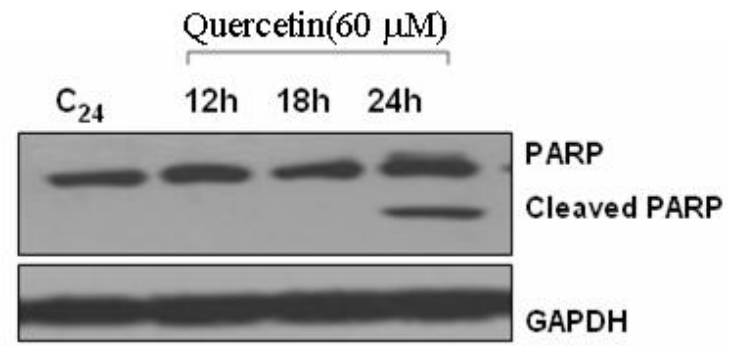

Figure 3: Apoptosis induced by quercetin in HepG2 cells. Western blot analysis of PARP in HepG2 cells treated with $60 \mu \mathrm{M}$ for different periods of time $(12,18$ and $24 \mathrm{~h}$ ).

\section{DISCUSSION}

Flavonol glycosides were the predominant constituents existing in S. bodinieri var. delicate, especially the quercetin glycosides [4,5]. As a result, methanol- $\mathrm{HCl}$ is a powerful extracting solvent for quercetin from the medicinal plant. It is not surprising that the content of quercetin was higher in methanol- $\mathrm{HCl}$ extract than the methanol extract. Macroporous resin column is frequently used to enrich the flavonoid compounds [9, 10]. Flavonol glycosides and other phenolic acids constituents were easily eluted by $30 \%$ ethanol from the macroporous resin column, while elution of flavonol aglycones required $70 \%$ or higher concentration ethanol. Hence, in the prsent study, we first used $30 \%$ ethanol to elute the phenolic acids and the unhydrolyzed flavonol glycosides. The flavonol aglycones-enriched fraction was further isolated by the Sephadex LH-20 column eluted by methanol. High purity quercetin was obtained by combination of the macroporous resin and Sephadex LH-20 columns.

The apoptotic effect of quercetin was examined by DAPI fluorescence staining in HepG2 cells. Incubation of cells for $24 \mathrm{~h}$ with quercetin alone resulted in numerous cells that had smaller nuclei with chromatin condensation and perinuclear apoptotic bodies. PARP is a DNA repair enzyme activated by DNA damage and the cleavage of PARP has been widely used as a biochemical marker of apoptosis [11]. Thus, we further studied PARP levels in HepG2 cells after exposure to quercetin. Our results indicate that $60 \mu \mathrm{M}$ quercetin can induce the PARP cleavage in a time-dependent manner. Quercetin showed potential apoptotic activity in the HepG2 cells.

\section{CONCLUSION}

A quick method to isolate high purity quercetin from $S$. bodinieri var. delicate has been developed for the first time. Successful evaluation of the isolated compound's antiproliferative potential and induction apoptosis activities in HepG2 cancer cells has been achieved.

\section{REFERENCES}

1. Chen J. Flora of China, 53(1). Science Press, Beijing: 1984; $p 140$.

2. Liao M, Zhang JW, Zhang YH. Screening on the Hepatoprotective Fractions of Sarcopyramis nepalensis. Herald of Medicine 2010; 5: 571-572.

3. Huang XG, Wan CP. Phytochemical Profiles and Antioxidant Properties of Sarcopyramis bodinieri var. delicate. Asian J Chem 2011; 23: 3581-3586.

4. Wan $C P$, Zheng $X$, Chen HF, Zou XH, Song ZR, Zhou $S R$, Qiu Y. Flavonoid constituents from herbs of Sarcopyramis bodinieri var. delicata. Zhongguo Zhong Yao Za Zhi 2009; 34: 172-174.

5. Wang XM, Wan CP, Zhou SR, Qiu Y. Two new flavonol glycosides from Sarcopyramis bodinieri var. delicate. Molecules 2008; 13: 1399-1405.

6. Yang JY, Wan CP, Qiu Y. Studies on the phenolic acids from Sarcopyramis bodinieri var. delicata. Zhong Yao Cai 2010; 4: 542-544.

7. Zuo AR, Wan CP, Zhou SR. Determination of quercetin in Sarcopyramis bodinieri var.delicata by HPLC. Hua Xi Yao Xue Za Zhi 2009; 3: 300-301.

8. Murugavel P, Pari L, Sitasawad SL, Kumar S, Kumar S. 
Cadmium induced mitochondrial injury and apoptosis in vero cells: protective effect of diallyl tetrasufide from garlic. Int J Biochem Cell B 2007; 39: 161-170.

9. Du HB, Wang $H$, Yu J, Liang CY, Ye WC, Li P. Enrichment and Purification of Total Flavonoid CGlycosides from Abrus mollis Extracts with Macroporous Resins. Ind Eng Chem Res 2012; 51: 7349-7354.
10. Qu LP, Xin HL, Su YH, Zheng GY, Ling CQ. Combined application of macroporous resin and high speed counter-current chromatography for preparative separation of three flavonoid triglycosides from the leaves of Actinidia valvata Dunn. J. Sep. Sci 2012; 35: 883-892.

11. Scovassi Al, Poirier GG. Poly(ADP-ribosylation) and apoptosis. Mol Cell Biochem 1999; 199: 125-137. 